\title{
First Report of FVC and FEV1 Reference Values for Beninese Children Aged 11-16 Years
}

\author{
Folly Messan, ${ }^{1}$ Pierre Dansou, ${ }^{1}$ Tanguy Marqueste, ${ }^{2}$ Patrick Decherchi, ${ }^{2}$ Richard Tossou, \\ Toussaint Amoussou, ${ }^{1}$ and Bénoîte Sovi-Guidi ${ }^{1}$ \\ ${ }^{1}$ Institut National de la Jeunesse, de l'Education Physique et du Sport (INJEPS), Université d'Abomey-Calavi, \\ 01 BP 169 Porto-Novo, Benin \\ ${ }^{2}$ Aix-Marseille Université (AMU), CP 910, 163 avenue de Luminy, 13009 Marseille, France
}

Correspondence should be addressed to Folly Messan; messfly@yahoo.fr

Received 12 May 2013; Accepted 17 July 2013

Academic Editors: A. Altraja, A. M. Boylan, A. Celi, A. Comellas, A. Miyazato, and A. Yokoyama

Copyright (C) 2013 Folly Messan et al. This is an open access article distributed under the Creative Commons Attribution License, which permits unrestricted use, distribution, and reproduction in any medium, provided the original work is properly cited.

\begin{abstract}
Background. The diagnosis of obstructive ventilatory disorders in children in Benin is not reliable despite the inclusion of ethnic correction factors for European standards (ERS-93) and the use of African-American standards (ITS-Black). Objectives. (1) Define standard values for forced vital capacity (FVC) and forced expiratory volume in the first second (FEV1) and (2) compare the FVC and FEV1 values observed in study subjects to those calculated by the ERS-93 and ITS-Black equations. Methods. FVC and FEV1 were measured using the MicroQuark Spirometer (Cosmed, Italy), and standing height was measured in 274 Beninese boys and 210 Beninese girls. The means and 95\% confidence intervals for these values were calculated by univariate analysis. Results. FVC and FEV1 values calculated using the ERS-93 equations were significantly higher $(P<0.05)$ than the measured values from our study. The percent change between the standard values in our study and the standards calculated using the ERS-93 and ITS-Black equations revealed differences between Beninese children and children of European or African-American descent. Conclusion. The differences observed between study samples and those derived from the ITS-Black and the ERS-93 equations should be used as ethnic correction factors.
\end{abstract}

\section{Introduction}

The diagnosis of bronchial obstruction, the early identification of lung diseases, the monitoring of lung growth, and the apogee and decline in lung function over time are all important characteristics to consider in the clinical management of respiratory disease. The assessment and management of respiratory diseases require reliable spirometry reference points for both static and dynamic lung volumes. To accomplish this, the effects of disease and of environmental influences on lung growth must be understood to avoid misdiagnoses. Ventilatory parameters observed in measurements of respiratory mechanics should be compared with spirometric reference values by sex, age, height, and ethnicity in accordance with the recommendations of the American Thoracic Society and the European Respiratory Society (ATS/ERS) $[1,2]$. Indeed, it is well established that these key variables affect ventilatory parameters, for example, height increases linearly with volume and pulmonary flow until the age of approximately 12 years for boys and 10 years for girls. However, the relationship between age and height varies from puberty until approximately 20 years of age [3-5]. Similarly, reference spirometry values have been established in Europeans who are aged from 18 to 70 years and who are 1.55 to $1.95 \mathrm{~m}$ in height for men and 1.45 to $1.80 \mathrm{~m}$ in height for women $[3,4]$ by the European Coal and Steel Community (CECA) $[6,7]$. However, spirometers imported into Africa are calibrated for the physical characteristics of Caucasian subjects who are exposed to different environmental and socioeconomic conditions than African subjects. African authors have shown that the lung volumes of African children are approximately $20 \%$ lower than those of Caucasian children of equal height [8]. These results have necessitated the use of correction factors [9] that are increasingly being integrated into the software of new generations of spirometers. Because of the differences observed between Caucasians and black Africans 
and of their environmental and socioeconomic differences, we hypothesize that, despite the ethnic corrections integrated into new spirometers, black African subjects have lower spirometric values than Caucasians and African-Americans of the same age, height, and sex. In the literature, both age and sex are causing spirometric information data loss for different age groups. Indeed, although significant differences have been observed between lung volumes for boys and girls aged from 6 to 16 years, Manzke et al. [10] compared subjects of the same age and sex. In addition, the "threshold" values below which ventilatory variables are considered abnormal are currently unreliable [ATS/ERS] [1]. It is therefore evident that standard values for European and American subjects cannot be properly applied to the African population. Under these conditions, it is necessary for countries in the southern Sahara, especially Benin, to have reliable, validated spirometric reference values. Therefore, this study, conducted on children and adolescents in Benin aged from 11 to 16 years, aims to (1) determine standard FVC and FEV1 values based on confidence intervals of height in each age group of girls and boys aged 11-16 years and (2) compare these standard values with those calculated from the ERS-93 [11] and ITSBlack [12] standard equations to determine ethnic correction factors.

\section{Materials and Methods}

2.1. Type and Scope of the Study. This was a multicenter study that was conducted from February to May 2011 on school children and students in five elementary schools and one secondary school in Porto-Novo (Benin). There were no health risks associated with participation in this study when a previously undiagnosed respiratory impairment was discovered; the individual was referred to a specialist for consultation and monitoring. All participants were fully informed about the purpose and ongoing progress of the study.

2.2. Experimental Protocol. On the day of the experiment, subjects completed a health status questionnaire; parents signed informed consent forms for younger participants (the ages under which parental consent was required were 11,12 , and 13). Individual subjects were weighed, and their height was measured and recorded. The same day, after $10 \mathrm{~min}-$ utes passive rest, spirometric measurements were recorded. Due to possible influences that can induce alterations in biorhythms, spirometric measurements were always taken in the morning from 10 to $12 \mathrm{a} . \mathrm{m}$. This study was approved by the Scientific Committee on Sectoral and Technical Sciences of Physical Activity and Sports (CSS/STAPS), University of Abomey, in accordance with the Helsinki Act of 1975.

2.3. Sampling. The number of subjects required for the study was determined using the following formula: $n=\left[Z^{2} * p(1-\right.$ $p)] / d^{2}$, where $n$ is the number of subjects required; $Z$ is the 95\% confidence interval $(Z=1.96) ; p$ is the estimation of the standard deviation of FEV (SD $=0.68$ according to the literature [13]); $q=1-p$, so $q=0.32$, and $d$ is the accuracy, set at $=4.1 \%$. Based on this formula, the required sample size was calculated to be 494 . Because of this, we enrolled 484 subjects.

2.4. Subject of the Study. The subjects were all students recruited by the Beninese simple probabilistic method and comprised a total of 274 Beninese boys and 210 Beninese girls, aged from 11 to 16 years (Table 1).

2.5. Inclusion and Exclusion Criteria. Both boys and girls subjects from Benin who were regularly enrolled in schools in Porto-Novo and aged from 11 to 16 years were selected to participate in the study. Exclusion criteria included history of smoking; current cardiovascular respiratory diseases; rheumatic diseases; subjects who are chronically exposed to automotive pollutants and biomass fuels; subjects undergoing treatment known to induce interference with any aspect of lung function; and subjects who were unable to perform the required respiratory maneuvers.

2.6. Medical Questionnaire and Anthropometric Data. Clinical data observed in the subjects were recorded using a respiratory questionnaire based on the questionnaire of the ATS [14]. The questionnaire was composed of questions written in French and translated into the local "Goun language". All questions were closed response, and most responses were dichotomous. Parents of some younger subjects were asked to answer on their behalf. According to the recommendations of the ATS/ERS [1], the height in centimeters, body mass in kilograms, and chronological age of the subjects were recorded. A SECA brand human scale, accurate to approximately $500 \mathrm{~g}$ with a maximum range of $150 \mathrm{~kg}$, was used to determine the body weight of each subject. A wall gauge measuring from zero to two meters was used to measure the height of the subjects standing barefoot and upright, with the head positioned in a Frankfort horizontal plane [15]. Body mass index $\left(\mathrm{BMI}=\right.$ mass divided by height square $\left.\left(\mathrm{kg} \cdot \mathrm{m}^{-2}\right)\right)$ was calculated for each age group, and the observed BMIs were reported in percentiles according to the guidelines of the "International Obesity Task Force" [16].

2.7. Pulmonary Function Tests. Flow/volume variables (FVC and FEV1) were measured using the MicroQuark Spirometer (Cosmed Ltd., Rome, Italy). Every morning, the spirometer was calibrated using a calibration syringe (Cosmed SARL, Rome, Italy) with a capacity of three liters of atmospheric air. The MicroQuark met the criteria of the ATS/ERS for measuring individuals of African origin. Indeed, the selection of "African origin" refers to the spirometer equations of African-American subject [12]. Mouthpieces and disposable antibacterial filters (Cosmed Ltd., Rome, Italy) were used to avoid cross contamination between subjects. Pulmonary function tests (PFT) were performed under the supervision of a medical technician. After determining the height, body weight, age, sex, and race of the individual, the spirometer unit automatically calculated the theoretical values of each respiratory parameter. In the PFT, the individual, while standing with nose pinched and a turbine between his hands, 
TABLE 1: Anthropometric characteristics and ventilatory parameters by sex and age from 11 to 16 years.

\begin{tabular}{llcccccc}
\hline & Age & 11 yrs & 12 yrs & 13 yrs & 14 yrs & 15 yrs & 16 yrs \\
\hline & (Girls) & $n=41$ & $n=44$ & $n=43$ & $n=29$ & $n=36$ & $n=17$ \\
& (Boys) & $n=47$ & $n=61$ & $n=42$ & $n=43$ & $n=49$ & $n=32$ \\
Height $(\mathrm{cm})$ & (Girls) & $144.9 \pm 6$ & $151.4 \pm 7$ & $151.0 \pm 7$ & $155.8 \pm 7$ & $155 \pm 5$ & $157.1 \pm 6$ \\
& (Boys) & $143.1 \pm 8$ & $149.6 \pm 10$ & $155.9 \pm 10^{*}$ & $159.5 \pm 9$ & $162.1 \pm 9^{* * *}$ & $164.3 \pm 9^{* *}$ \\
BM $(\mathrm{kg})$ & (Girls) & $35.3 \pm 6$ & $40.8 \pm 8$ & $43.6 \pm 8$ & $46.9 \pm 8$ & $46.9 \pm 10$ & $49.9 \pm 5$ \\
& (Boys) & $33.6 \pm 6$ & $38.5 \pm 9$ & $42.4 \pm 9$ & $46.3 \pm 9$ & $47.8 \pm 8$ & $50.1 \pm 9$ \\
BMI $\left(\mathrm{kg} / \mathrm{m}^{2}\right)$ & (Girls) & $16.7 \pm 2.4$ & $17.7 \pm 2.6$ & $19.0 \pm 3.3^{* *}$ & $19.9 \pm 2.9^{* *}$ & $19.5 \pm 2.0^{* *}$ & $20.3 \pm 2.2^{* *}$ \\
& (Boys) & $16.2 \pm 2.0$ & $17.0 \pm 2.6$ & $17.21 \pm 2.5$ & $18.1 \pm 2.7$ & $18.1 \pm 2.0$ & $18.4 \pm 2.0$ \\
FVC $(\mathrm{L})$ & (Girls) & $1.85 \pm 0.4$ & $1.94 \pm 0.5$ & $2.19 \pm 0.5$ & $2.29 \pm 0.3$ & $2.39 \pm 0.4$ & $2.71 \pm 0.5$ \\
& (Boys) & $2.06 \pm 0.5^{*}$ & $2.22 \pm 0.5^{* *}$ & $2.57 \pm 0.6^{* *}$ & $2.78 \pm 0.6^{* *}$ & $2.99 \pm 0.7^{* * *}$ & $3.21 \pm 0.7^{*}$ \\
$\mathrm{FEV}_{1}(\mathrm{~L})$ & (Girls) & $1.47 \pm 0.4$ & $1.49 \pm 0.5$ & $1.72 \pm 0.4$ & $1.93 \pm 0.4$ & $1.88 \pm 0.3$ & $2.05 \pm 0.6$ \\
& (Boys) & $1.59 \pm 0.4$ & $1.74 \pm 0.5^{* *}$ & $2.03 \pm 0.6^{* *}$ & $2.23 \pm 0.6^{* *}$ & $2.16 \pm 0.5^{* *}$ & $2.20 \pm 0.6$ \\
\hline
\end{tabular}

BM: body mass; BMI: body mass index; FVC: force vital capacity; $\mathrm{FEV}_{1}$ : Force expiratory in one second. Values are means \pm SD. ${ }^{*}$ Significant difference between boys and girls. ${ }^{*} P<0.05 ;{ }^{* *} P<0.01$; ${ }^{* * *} P<0.001$.

breathed naturally and quietly through the mouthpiece connected to the spirometer. The individual was then instructed to inflate lungs and then exhale the air, as quickly and completely as possible, in a continuous way. At the end of the test, the flow-volume curve (FVC + FEV1) was calculated in accordance with the acceptance criteria recommended by the ATS/ERS [17].

2.8. Determination of Standard FVC and FEV1 Values and ERS-93 and ITS-Black Standards in Our Study. The magnitude of the FVC and FEV1 values measured in the subjects from each age group and sex was subjected to univariate analysis to determine means as well as confidence interval (our results). The mean heights were then introduced into the ERS-93 [11] and ITS-Black [12] equations by age and sex to determine reference FVC and FEV1 values. The differences between the standard values determined by our study and the ERS-93 [11] and ITS-Black [12] standards are presented as the percent change over the standard.

The ERS-93 Equations [11]. For boys children aged 18 years and under,

$$
\begin{aligned}
& \mathrm{FVC}=7.9942-0.12509 * H+0.000605 * \\
& H^{2} ; \mathrm{SD}: 0.393, \\
& \mathrm{FEV} 1=6.6314-0.10261 * H+0.000499 * \\
& H^{2} ; \mathrm{SD}: 0.523 .
\end{aligned}
$$

For girls children aged 18 years and under,

$$
\begin{aligned}
& \mathrm{FVC}=0.169-0.01217 * H * 0.000189 * H^{2} ; \mathrm{SD}: 0.263 \\
& \mathrm{FEV} 1=0.0364 * H-3.0378 ; \mathrm{SD}: 0.42
\end{aligned}
$$

The ITS-Black Equations [12]. For boys children aged 18 years and under,

$$
\begin{aligned}
& \mathrm{FVC}=0.00107 * H^{2.93} / 1000 ; \mathrm{SD}: 1.048 \\
& \mathrm{FEV} 1=0.00103 * H^{2.92} / 1000 ; \mathrm{SD}: 0.932
\end{aligned}
$$

For girls children aged 18 years and under,

$$
\begin{aligned}
& \mathrm{FVC}=0.000834 * H^{2.98} / 1000 ; \mathrm{SD}: 0.076 \\
& \mathrm{FEV} 1=0.00114 * H^{2.89} / 1000 ; \mathrm{SD}: 0.622
\end{aligned}
$$

Note. The variables FVC and FEV1 are in liters, and height $(H)$ is in centimeters. SD is the standard deviation.

Statistical Analysis. The variables were processed using Stat View 5 software (version 5) (Abacus Concepts Inc., Berkeley, CA, USA). Descriptive statistics were generated for each variable. The normal distribution of variables, as well as the equivalence of their respective variances, was checked by the Kolmogorov-Smirnov test and the $F$-test. The magnitude of the FVC and FEV1 values measured in the subjects from each age group and sex was subjected to univariate analysis to determine means as well as confidence interval. Comparisons between groups were performed by unpaired $t$-tests after the normality of the distribution and homogeneity of variances were verified. For all statistical analyses, the null hypothesis was rejected at a probability of $P<0.05$.

\section{Results}

3.1. Descriptive Data. Table 1 shows the physical characteristics and the distribution of results by sex and age, from 11 to 16 years. Boys are significantly larger at ages 13,15 , and 16 compared with girls. Conversely, girls from ages 13 to 16 years have a significantly higher body mass index when compared with boys of the same age. The mean FVC and FEV1 values observed were significantly higher in boys than in girls regardless of age group, with the exception of FEV1 in 11-year-old children. Table 2 shows that, regardless of the sex, peak dynamic growth in height and body mass was reached at 11 or 12 years of age. In contrast, peak dynamic FVC and FEV1 were observed in 12- to 13-year-old children independent of sex.

3.2. Spirometric Standard Reference Values. Tables 3 and 4 present the standard and confidence intervals for the variable size and the standard and confidence intervals for FVC and 
TABLE 2: Dynamic growth of Height, Body mass, FVC and FEV, by sex and age from 11 to 16 years.

\begin{tabular}{|c|c|c|c|c|c|c|}
\hline & & [11-12] yrs & [12-13] yrs & [13-14] yrs & [14-15] yrs & [15-16] yrs \\
\hline \multirow{2}{*}{ Height (\%) } & (Girls) & 4.49 & 0.00 & 3.18 & 0.51 & 1.35 \\
\hline & (Boys) & 4.54 & 4.21 & 2.31 & 1.63 & 1.36 \\
\hline \multirow{2}{*}{ BM (\%) } & (Girls) & 15.58 & 6.86 & 7.57 & 0.00 & 6.40 \\
\hline & (Boys) & 14.58 & 10.13 & 9.20 & 3.24 & 4.81 \\
\hline \multirow{2}{*}{ FVC (\%) } & (Girls) & 4.86 & 12.89 & 4.57 & 4.37 & 13.39 \\
\hline & (Boys) & 7.77 & 15.77 & 8.17 & 7.55 & 7.36 \\
\hline \multirow{2}{*}{$\mathrm{FEV}_{1}(\%)$} & (Girls) & 1.36 & 15.44 & 12.21 & -2.59 & 9.04 \\
\hline & (Boys) & 9.43 & 16.67 & 9.85 & -3.14 & 1.85 \\
\hline
\end{tabular}

BM: body mass; BMI: body mass index; FVC: force vital capacity; FEV: force expiratory in one second. Values are percent changes from one age group to another.

TABLE 3: FVC and $\mathrm{FEV}_{1}$ values measured from our study compared to those calculated using the ITS-Black equations.

\begin{tabular}{|c|c|c|c|c|c|c|c|c|c|c|}
\hline $\begin{array}{l}\text { (A) } \\
\text { Age } \\
\text { Year } \\
\text { (Sex) }\end{array}$ & $\begin{array}{l}\text { (B) } \\
\text { IC_height } \\
(\mathrm{cm})\end{array}$ & $\begin{array}{c}(\mathrm{C}) \\
\text { height } \\
(\mathrm{cm}) \\
\text { standard }\end{array}$ & $\begin{array}{c}\text { (D) } \\
\text { IC_FVC } \\
\text { (L) } \\
\text { our } \\
\text { study }\end{array}$ & $\begin{array}{c}(\mathrm{E}) \\
\text { FVC } \\
(\mathrm{L}) \\
\text { our } \\
\text { standard }\end{array}$ & $\begin{array}{c}(\mathrm{F}) \\
\text { FVC } \\
(\mathrm{L}) \\
\text { equation } \\
\text { ITS-Black }\end{array}$ & $\begin{array}{c}(\mathrm{G}) \\
\text { Delta } \\
\%\end{array}$ & $\begin{array}{c}(\mathrm{H}) \\
\mathrm{IC}_{\mathrm{C}} \mathrm{FEV} \\
(\mathrm{L}) \\
\text { our } \\
\text { standard }\end{array}$ & $\begin{array}{c}\text { (I) } \\
\mathrm{FEV}_{1}(\mathrm{~L}) \\
\text { our } \\
\text { study }\end{array}$ & $\begin{array}{c}(\mathrm{J}) \\
\mathrm{FEV}_{1}(\mathrm{~L}) \\
\text { equation } \\
\text { ITS Black }\end{array}$ & $\begin{array}{c}(\mathrm{K}) \\
\text { Delta } \\
\%\end{array}$ \\
\hline $\begin{array}{l}11 \text { yrs } \\
\text { (Boys) }\end{array}$ & {$[140.7 ; 145.5]$} & 143.1 & {$[1.91 ; 2.21]$} & 2.06 & $2.21^{\S}$ & +7.53 & {$[1.46 ; 1.72]$} & 1.59 & $2.03^{*}$ & +27.62 \\
\hline $\begin{array}{l}12 \text { yrs } \\
\text { (Boys) }\end{array}$ & {$[147.0 ; 152.2]$} & 149.6 & {$[2.08 ; 2.36]$} & 2.22 & $2.52^{*}$ & +13.65 & {$[1.62 ; 1.86]$} & 1.73 & $2.31^{*}$ & +33.53 \\
\hline $\begin{array}{l}13 \text { yrs } \\
\text { (Boys) }\end{array}$ & [152.6; 159.3] & 155.9 & {$[2.36 ; 2.78]$} & 2.57 & $2.85^{*}$ & +10.79 & {$[1.84 ; 2.21]$} & 2.03 & $2.61^{*}$ & +28.37 \\
\hline $\begin{array}{l}14 \text { yrs } \\
\text { (Boys) }\end{array}$ & {$[156.5 ; 162.4]$} & 159.4 & {$[2.59 ; 2.97]$} & 2.78 & $3.04^{*}$ & +9.30 & {$[2.06 ; 2.41]$} & 2.23 & $2.78^{*}$ & +24.68 \\
\hline $\begin{array}{l}15 \text { yrs } \\
\text { (Boys) }\end{array}$ & {$[159.4 ; 164.9]$} & 162.1 & {$[2.79 ; 3.19]$} & 2.99 & $3.19^{\S}$ & +6.75 & {$[2.00 ; 2.31]$} & 2.16 & $2.92^{*}$ & +35.19 \\
\hline $\begin{array}{l}16 \text { yrs } \\
\text { (Boys) }\end{array}$ & {$[160.7 ; 168.0]$} & 164.3 & {$[2.95 ; 3.46]$} & 3.21 & $3.32^{\S}$ & +3.44 & {$[1.99 ; 2.42]$} & 2.20 & $3.04^{*}$ & +38.06 \\
\hline $\begin{array}{l}11 \text { yrs } \\
\text { (Girls) }\end{array}$ & {$[143.1 ; 146.8]$} & 144.9 & {$[1.72 ; 1.98]$} & 1.85 & $2.30^{*}$ & +24.16 & {$[1.35 ; 1.58]$} & 1.47 & $2.01^{*}$ & +36.48 \\
\hline $\begin{array}{l}12 \text { yrs } \\
\text { (Girls) }\end{array}$ & {$[149.1 ; 153.8]$} & 151.4 & {$[1.80 ; 2.08]$} & 1.94 & $2.62^{*}$ & +34.94 & {$[1.34 ; 1.64]$} & 1.49 & $2.28^{*}$ & +52.86 \\
\hline $\begin{array}{l}13 \text { yrs } \\
\text { (Girls) }\end{array}$ & {$[148.8 ; 153.2]$} & 151.0 & {$[2.04 ; 2.34]$} & 2.19 & $2.60^{*}$ & +18.60 & {$[1.58 ; 1.85]$} & 1.72 & $2.26^{*}$ & +31.41 \\
\hline $\begin{array}{l}14 \text { yrs } \\
\text { (Girls) }\end{array}$ & {$[139.3 ; 161.5]$} & 150.4 & {$[2.16 ; 2.42]$} & 2.29 & $2.57^{*}$ & +12.08 & {$[1.77 ; 2.10]$} & 1.93 & $2.23^{*}$ & +15.77 \\
\hline $\begin{array}{l}15 \text { yrs } \\
\text { (Girls) }\end{array}$ & {$[153.3 ; 156.7]$} & 154.9 & {$[2.24 ; 2.54]$} & 2.39 & $2.80^{*}$ & +17.25 & {$[1.75 ; 2.01]$} & 1.88 & $2.43^{*}$ & +29.42 \\
\hline $\begin{array}{l}16 \text { yrs } \\
\text { (Girls) }\end{array}$ & {$[153.8 ; 160.4]$} & 157.0 & {$[2.46 ; 2.96]$} & 2.71 & $2.92^{\S}$ & +7.64 & {$[1.76 ; 2.35]$} & 2.05 & $2.53^{*}$ & +23.40 \\
\hline
\end{tabular}

(A): different categories of age, year, and sex (B); confidence intervals (CI) of height; (C): reference values of height compatible with IC; (D): IC of FVC; (E): standard values of FVC according to IC; (F): FVC values obtained after introducing the referential height in ERS-93 equation; $(\mathrm{G})$ : $(\mathrm{F} * 100 / \mathrm{E})-100 ;(\mathrm{H})$ : $\mathrm{CI}$ of $\mathrm{FEV}_{1}$; (I): standard values of $\mathrm{FEV}_{1}$ according to IC; $(\mathrm{J})$ : $\mathrm{FEV}_{1}$ values obtained after introducing of the referential height in ITS-Black equation; (K) (J * $100 / \mathrm{I})-100 ;{ }^{*}$ ITS-Black values significantly different $(P<0.05)$ from standard values in our study. ${ }^{8}$ No significant difference between the standard values of our study and the standards ITS-Black.

FEV1. Each variable also has validated reference confidence interval for each age group and both sexes. BMI values observed in different age groups were confirmed to be within the 40th and 60th percentiles using IOTF [16] curves. The standard height values were then introduced into the ERS93 [11] and ITS-Black [12] equations to calculate reference FVC and FEV1 values. Our standard FVC and FEV1 values were then compared with the ERS-93 [11] and ITS-Black [12] standards.

3.3. Comparisons of Our Standards with ITS-Black Standards. The FVCs of 11-, 15-, and 16-year-old boys and those of 16year-old girls in our study were not significantly different 
$(P>0.05)$ from the ITS-Black standards (Table 3). In contrast, the FVCs for 12- to 14-year-old boys and 11- to 15year-old girls calculated using the ITS-Black [12] equations were significantly higher $(P<0.05)$ than those observed in our study. The ITS-Black [12] FEV1 standard values were significantly higher $(P<0.05)$ than those observed in our study regardless of age group or sex.

3.4. Comparisons of Our Standards with ERS-93 Standards. FEV1 and FVC values calculated using ERS-93 [11] equations were significantly higher than those observed in our study regardless of age group or sex (Table 4).

3.5. Correction Factors. The percentages of variations from these standards serve as correction factors for pulmonary function of children in Benin. All of the corrections lowered individual ventilatory variables (Table 5).

\section{Discussion}

The major findings of this study show that ERS-93 [11] standards do not accurately predict FVC and FEV1 in Beninese children and adolescents. Indeed, these ventilatory variables were significantly overestimated. In contrast, the FVCs predicted by the ITS-Black [12] standard for 11-, 15-, and 16-year-old boys and 16-year-old girls are acceptable. The study suggests that new "African" correction factors are required.

Methods. The determination of spirometric reference values is a common practice. Studies in several countries have already aimed to determine reference equations for children and healthy adults according to age, sex, height, and even ethnic group. Two groups of equations commonly used are the equations of the European Coal and Steel Community (ECSC) [18] and the equations from the third National Health and Nutrition Examination Survey (NHANES III) [19]. These two main equation sets are predictive, and those published in the literature are multiple regressions that simultaneously integrate several variables including age, height, and sex. However, it is clear that when a final value is determined by such an equation using several measured variables, the total calculated error equals the sum of the errors on each individual variable. Sub-Saharan African countries, particularly Benin, do not yet have tools with which spirometry is validated.This study aimed to develop standard of FVC and FEV1 values with 95\% confidence intervals for children in each age group which would allow the exclusion of the effects of age- and sex-related lung maturation and growth. The type of study may explain any variable results in reference spirometry values. Indeed, Ware et al. [20] observed both cohort and period effects in longitudinal studies, while Guénard and Rouatbi [21] highlighted the effects of selection that are specific to cross-sectional studies. In general, reference equations are based on cross-sectional samples obtained at the same time and in patients of all ages. Variability in lung function over time is often minimized because of linear age. To eliminate significant differences between references equations, study sample sizes should minimally be 100 subjects [22]; our sample size of 484 subjects greatly exceeds this requirement. The distribution of ventilatory variables was evaluated by the Kolmogorov-Smirnov test and was determined to be normal. The lower limit of normal was considered to be equal to the lower limit of the 95\% CI $[1,23]$.

Comparisons of Our Standard Values with Those of ITS-Black and ERS-93. Tables 3 and 4 present the results of comparisons between ventilatory variables from the present study with the ITS-Black [12] and ERS-93 [11] standards.

ITS-Black. The mean FVC values observed in boys aged 11, 15 , and 16 years using the ITS-Black [12] equation standards were not significantly $(P>0.05)$ greater than those in our study; the observed increases were $7.53 \%, 6.75 \%$, and $3.44 \%$, respectively. The same observation was recorded in girls, with an increase $(P>0.05)$ of $7.64 \%$. For these age groups of Beninese subjects, the ITS-Black standard equations can be used. In contrast, the increases in boys age 12,13 , and 14 years which were $13.65 \%, 10.79 \%$, and $9.30 \%$, respectively, were statistically significant $(P<0.05)$. In addition, in boys and in all age categories, the average FEV1 value was significantly increased $(P<0.05)$ by $31.35 \%$ when compared with the average standard in our study.

ERS-93 Standards. In girls and boys of all age groups considered, the mean FVC and FEV1 values observed using ERS-93 [11] standards significantly $(P<0.05)$ exceeded the standard values in our study (Table 4$)$.

In sum, the variable FVC observed in Beninese children can be predicted using the ITS-Black standard for the 11-, 15 -, and 16-year-old age groups. It should be noted that the ITS-Black reference standard values were established using the physical characteristics of African-American subjects. Studies show that the ancestors of African-Americans were slaves who were forcibly brought from Africa to the Americas. The work of Jordan [24] showed that the DNA evidence supports the degrees of relationship as determined by both genetic history and morphology. In this study, these results partially justify the observed variance in FVC between young Africans and African-Americans. That same study [24] showed that Europeans form a compact group that is clearly separated from African populations. These results suggest an explanation for differences in observed FVC and FEV1 values between girls and boys in all age categories independent of sex and the European ERS-93 [11] standards. Indeed, these standards significantly overestimate FVC and FEV1 values in Beninese children. Similar results were observed by Aggarwal et al. [25] who noted in 6814 subjects reported to have normal spirometry that, according to Indian references, $53 \%, 40 \%, 14 \%$, and $10 \%$ of these subjects were identified as having abnormal spirometry according to NHANES III [19], European standards and Crapo [26], and Knudson et al. [27].Similarly, studies in Nigerian schoolchildren aged 5 to 20 years have demonstrated mean FVC and FEV1 values that were significantly lower than those of their white counterparts [28]. In this sense, in the interpretation of pulmonary function in children, some authors $[29,30]$ emphasize the importance of ethnic impact. Therefore, the interpretation of static lung volumes among black children 
TABLE 4: FVC and $\mathrm{FEV}_{1}$ values measured from our study compared to that calculated using the ERS-93 equations.

\begin{tabular}{|c|c|c|c|c|c|c|c|c|c|c|}
\hline $\begin{array}{l}\text { (A) } \\
\text { Age } \\
\text { Year } \\
\text { (Sex) }\end{array}$ & $\begin{array}{l}\text { (B) } \\
\text { CI_height } \\
(\mathrm{cm})\end{array}$ & $\begin{array}{c}(\mathrm{C}) \\
\text { Height } \\
(\mathrm{cm}) \\
\text { standard }\end{array}$ & $\begin{array}{c}\text { (D) } \\
\text { CI_FVC } \\
\text { (L) } \\
\text { our } \\
\text { study }\end{array}$ & $\begin{array}{l}\text { (E) } \\
\text { FVC } \\
(\mathrm{L}) \\
\text { our } \\
\text { study }\end{array}$ & $\begin{array}{c}\text { (F) } \\
\text { FVC } \\
(\mathrm{L}) \\
\text { equation } \\
\text { ERS-93 }\end{array}$ & $\begin{array}{c}(\mathrm{G}) \\
\text { Delta } \\
\%\end{array}$ & $\begin{array}{c}(\mathrm{H}) \\
\text { CI_FEV }_{1} \\
(\mathrm{~L}) \\
\text { our } \\
\text { study }\end{array}$ & $\begin{array}{c}\text { (I) } \\
\mathrm{FEV}_{1}(\mathrm{~L}) \\
\text { our } \\
\text { study }\end{array}$ & $\begin{array}{c}(\mathrm{J}) \\
\mathrm{FEV}_{1}(\mathrm{~L}) \\
\text { equation } \\
\text { ERS-93 }\end{array}$ & $\begin{array}{c}(\mathrm{K}) \\
\text { Delta } \\
\%\end{array}$ \\
\hline $\begin{array}{l}11 \text { yrs } \\
\text { (Boys) }\end{array}$ & {$[140.7 ; 145.5]$} & 143.1 & {$[1.91 ; 2.21]$} & 2.06 & $2.48^{*}$ & +20.52 & {$[1.46 ; 1.72]$} & 1.59 & $2.17^{*}$ & +36.24 \\
\hline $\begin{array}{l}12 \text { yrs } \\
\text { (Boys) }\end{array}$ & {$[147.0 ; 152.2]$} & 149.6 & {$[2.08 ; 2.36]$} & 2.22 & $2.82^{*}$ & +27.06 & {$[1.62 ; 1.86]$} & 1.73 & $2.45^{*}$ & +41.54 \\
\hline $\begin{array}{l}13 \text { yrs } \\
\text { (Boys) }\end{array}$ & {$[152.6 ; 159.3]$} & 155.9 & {$[2.36 ; 2.78]$} & 2.57 & $3.20^{*}$ & +24.40 & {$[1.84 ; 2.21]$} & 2.03 & $2.76^{*}$ & +36.09 \\
\hline $\begin{array}{l}14 \text { yrs } \\
\text { (Boys) }\end{array}$ & {$[156.5 ; 162.4]$} & 159.4 & {$[2.59 ; 2.97]$} & 2.78 & $3.43^{*}$ & +23.27 & {$[2.06 ; 2.41]$} & 2.23 & $2.95^{*}$ & +32.47 \\
\hline $\begin{array}{l}15 \text { yrs } \\
\text { (Boys) }\end{array}$ & {$[159.4 ; 164.9]$} & 162.1 & {$[2.79 ; 3.19]$} & 2.99 & $3.61^{*}$ & +20.88 & {$[2.00 ; 2.31]$} & 2.16 & $3.11^{*}$ & +43.99 \\
\hline $\begin{array}{l}16 \text { yrs } \\
\text { (Boys) }\end{array}$ & {$[160.7 ; 168.0]$} & 164.3 & {$[2.95 ; 3.46]$} & 3.21 & $3.77^{*}$ & +17.56 & {$[1.99 ; 2.42]$} & 2.20 & $3.24^{*}$ & +47.40 \\
\hline $\begin{array}{l}11 \text { yrs } \\
\text { (Girls) }\end{array}$ & {$[143.1 ; 146.8]$} & 144.9 & {$[1.72 ; 1.98]$} & 1.85 & $2.37^{*}$ & +28.31 & {$[1.35 ; 1.58]$} & 1.46 & $2.24^{*}$ & +53.19 \\
\hline $\begin{array}{l}12 \text { yrs } \\
\text { (Girls) }\end{array}$ & {$[149.1 ; 153.8]$} & 151.4 & {$[1.80 ; 2.08]$} & 1.94 & $2.66^{*}$ & +37.05 & {$[1.34 ; 1.64]$} & 1.49 & $2.47^{*}$ & +65.98 \\
\hline $\begin{array}{l}13 \text { yrs } \\
\text { (Girls) }\end{array}$ & {$[148.8 ; 153.2]$} & 151.0 & {$[2.04 ; 2.34]$} & 2.19 & $2.64^{*}$ & +20.58 & {$[1.58 ; 1.85]$} & 1.72 & $2.46^{*}$ & +42.94 \\
\hline $\begin{array}{l}14 \text { yrs } \\
\text { (Girls) }\end{array}$ & {$[139.3 ; 161.5]$} & 150.4 & {$[2.16 ; 2.42]$} & 2.29 & $2.61^{*}$ & +14.14 & {$[1.77 ; 2.10]$} & 1.93 & $2.44^{*}$ & +26.26 \\
\hline $\begin{array}{l}15 \text { yrs } \\
\text { (Girls) }\end{array}$ & {$[153.3 ; 156.7]$} & 154.9 & {$[2.24 ; 2.54]$} & 2.39 & $2.82^{*}$ & +17.94 & {$[1.75 ; 2.01]$} & 1.88 & $2.60^{*}$ & +38.33 \\
\hline $\begin{array}{l}16 \text { yrs } \\
\text { (Girls) }\end{array}$ & {$[153.8 ; 160.4]$} & 157.0 & {$[2.46 ; 2.96]$} & 2.71 & $2.98^{*}$ & +7.64 & {$[1.76 ; 2.35]$} & 2.05 & $2.68^{*}$ & +30.59 \\
\hline
\end{tabular}

(A): different categories of age, year, and sex; (B): confidence intervals (CI) of height; (C): reference values of height compatible with IC; (D): IC of FVC; (E) standard values of FVC according to IC; (F): FVC values obtained after introducing of the referential height in ERS/93 equation; (G): (F* 100/E) - 100; (H): CI of $\mathrm{FEV}_{1}$; (I): standard values of $\mathrm{FEV}_{1}$ according to IC; $(\mathrm{J})$ : $\mathrm{FEV}_{1}$ values obtained after introducing of the referential height in ERS-93 equation; (K): (J * 100/I) $100 ;{ }^{*}$ ERS-93 values significantly different $(P<0.05)$ from standard values in our study.

TABLE 5: Correction ethnic factors suggested by our study in Beninese children after using the microQuark Spirometer (Cosmed, Italy) with "African origin" option.

\begin{tabular}{|c|c|c|c|}
\hline $\begin{array}{l}\text { (A) } \\
\text { Age } \\
\text { Year } \\
\text { (Sex) }\end{array}$ & $\begin{array}{c}(\mathrm{B}) \\
\text { IC_height }(\mathrm{cm})\end{array}$ & $\begin{array}{c}(\mathrm{C}) \\
\text { Correction } \\
\text { ethnic of FVC } \\
(\%)\end{array}$ & $\begin{array}{c}\text { (D) } \\
\text { Correction } \\
\text { ethnic of } \mathrm{FEV}_{1} \\
(\%)\end{array}$ \\
\hline 11 yrs (Boys) & {$[140.7 ; 145.5]$} & -7.53 & -27.62 \\
\hline 12 yrs (Boys) & {$[147.0 ; 152.2]$} & -13.65 & -33.53 \\
\hline 13 yrs (Boys) & {$[152.6 ; 159.3]$} & -10.79 & -28.37 \\
\hline 14 yrs (Boys) & {$[156.5 ; 162.4]$} & -9.30 & -24.68 \\
\hline 15 yrs (Boys) & {$[159.4 ; 164.9]$} & -6.75 & -35.19 \\
\hline 16 yrs (Boys) & {$[160.7 ; 168.0]$} & -3.44 & -38.06 \\
\hline 11 yrs (Girls) & {$[143.1 ; 146.8]$} & -24.16 & -36.48 \\
\hline 12 yrs (Girls) & [149.1; 153.8] & -34.94 & -52.86 \\
\hline 13 yrs (Girls) & {$[148.8 ; 153.2]$} & -18.60 & -31.41 \\
\hline 14 yrs (Girls) & {$[139.3 ; 161.5]$} & -12.08 & -15.77 \\
\hline 15 yrs (Girls) & {$[153.3 ; 156.7]$} & -17.25 & -29.42 \\
\hline 16 yrs (Girls) & {$[153.8 ; 160.4]$} & -7.64 & -23.40 \\
\hline
\end{tabular}

(A): different categories of age, year, and sex, (B): confidence intervals (CI) of height, (C) and (D): correction ethnic values of FVC and FEV observed respectively, with the microQuark Spirometer. 
is limited due to inappropriate reference equations. The reference equations cannot be applied to people unless they have similar morphological, socioeconomic, and ethnic characteristics. To minimize these biases, the ATS/ERS [1] jointly recommended the application of ethnic groups correction factors to subjects for whom there are no specific equations available. However, in 1999, Hankinson et al. [19] were already questioning the validity of these correction factors. Indeed, in the context of this study, the original "African" factor was taken into account by the MicroQuark spirometer (Cosmed Ltd, Rome, Italy) software to correct the difference between black and Caucasian subjects. If this factor was accurate, the measurement of ventilatory parameters using this spirometry would not present significant differences between black and Caucasian subjects of the same age and height. Despite these corrective measures, the "corrected" European standards significantly overestimated the predicted ventilation variables in Beninese subjects. Similarly, Dufetel et al. [31] showed in Africa, among Togolese men aged 25 to 55 years, that total lung capacity was, on average, $25 \%$ lower and that other lung volumes were also $22 \%$ lower when compared with Caucasian men of similar age and size. In this context, Dufetel et al. [31] concluded that it would be inappropriate to use a proportionality factor to define the reference spirometric values of black children from the standards defined for Caucasians. The following question arises; despite the integrated ethnic corrections in spirometers imported from Europe, why are the ventilatory variables measured in subjects higher in black Africans than in their Caucasian counterparts of the same sex, age, and height? The answer to this question has several parts. Indeed, Dufetel et al. [8] have explained this difference by the fact that black children have smaller rib cages and longer limbs than those of Caucasian children, confirming that growth rates are different between ethnic groups. For example, in Brazil, this fact is taken into account because the spirometric reference values applicable to Brazilian white adults differ from those of other ethnicities [32]; additionally, Pellegrino et al. [1] explained these differences as being a result of variability in the characteristics of the study groups such as age, height, and sex. In the populations studied herein, the equations were significantly different by sex. Indeed, for each sex, there is an age effect and a height effect because young subjects are at different stages of lung maturation and growth. These effects are often masked because subjects are not distinguished based on height and age. To overcome these difficulties and biases in the context of this study, we opted to evaluate each age group from 11 to 16 years separately. At another level, Stanojevic et al. [33] explained this discrepancy by stating that the values embedded in spirometry software can vary significantly both from one manufacturer to another and between research laboratories [34]. Finally, a question was raised regarding precisely how much of an effect age has on the variability of reference spirometric data. Indeed, in the studies that led to predictive equations, the chronological ages of subjects often considered were accurate for all ages. For example, a subject born in early January or in late December will have the same chronological age in January or December of the same year. Under these conditions, according to Marks [35], are spirometric reference equations really appropriate for diagnosing lung diseases? This is precisely what Quanjer et al. [36] avoided using the "Global Lung Function Initiative" frame work which has developed a software tool that allows accurate determination of the age of the subject based on the date of birth and the day of the experiment. Obviously, these ages are measured using decimals. The specific problem of age is especially critical in Africa, especially given that thousands of children do not have birth certificates. Similarly, the present study was based on chronological age. Equations "imported" into Africa are completely mismatched, and anthropological and environmental realities are very different from those of Europe, thus motivating many current researchers to build their own reference spirometry; a review of the current literature counts more than 250 references equations in use worldwide. Perhaps these isolated initiatives will contribute to the project of universalization "Multi-Ethnic reference values for spirometry for the 3-95 yr age-range" which is available online on the website of the International Global Lung Initiative (http://www.lungfunction.org) [32].

In conclusion, the present study assessed growth dynamics, morphological spirometry, and standard FVC and FEV1 values that were adapted to the physical characteristics, ethnicity and specific environments of Beninese children. These reference values, specific to blacks, can be used with their counterparts in subregions that do not yet have reference values. Obviously, these standard values allow early detection by pediatricians and clinicians of lung diseases, growth problems, and malnutrition in a specific context. The results of this study represent a significant advance that should be extended to other regions of Benin in subjects of the same age groups.

\section{References}

[1] R. Pellegrino, G. Viegi, V. Brusasco et al., "Interpretative strategies for lung function tests," European Respiratory Journal, vol. 26, no. 5, pp. 948-968, 2005.

[2] R. O. Crapo, "The role of reference values in interpreting lung function tests," European Respiratory Journal, vol. 24, no. 3, pp. 341-342, 2004.

[3] X. Wang, D. W. Dockery, D. Wypij, M. E. Fay, and B. G. Ferris Jr., "Pulmonary function between 6 and 18 years of age," Pediatric Pulmonology, vol. 15, no. 2, pp. 75-88, 1993.

[4] S. Stanojevic, A. Wade, J. Stocks et al., "Reference ranges for spirometry across all ages: a new approach," American Journal of Respiratory and Critical Care Medicine, vol. 177, no. 3, pp. 253260, 2008.

[5] M. Takase, H. Sakata, M. Shikada, K. Tatara, T. Fukushima, and T. Miyakawa, "Development of reference equations for spirometry in japanese children aged 6-18 years," Pediatric Pulmonology, vol. 48, no. 1, pp. 35-44, 2013.

[6] "Seconde edition française des recommandations européennes pour les explorations fonctionnelles respiratoires," La Revue des Maladies Respiratoires, vol. 18, no. 6S, pp. 13-52, 2001.

[7] P. H. Quanjer, "Standardized lung function testing," Bulletin Européen de Physiopathologie Respiratoire, vol. 19, supplement 5, pp. 1-95, 1983.

[8] P. Dufetel, A. Wazni, C. Gaultier, G. Derossi, F. Cisse, and J. P. Martineaud, "Growth and ventilatory function in black children 
and adolescents," Revue des Maladies Respiratoires, vol. 12, no. 2, pp. 135-143, 1995.

[9] C. E. Rossiter and H. Weill, "Ethnic differences in lung function: evidence for proportional differences," International Journal of Epidemiology, vol. 3, no. 1, pp. 55-61, 1974.

[10] H. Manzke, E. Stadlober, and H.-P. Schellauf, "Combined body plethysmographic, spirometric and flow volume reference values for male and female children aged 6 to 16 years obtained from "hospital normals"', European Journal of Pediatrics, vol. 160, no. 5, pp. 300-306, 2001.

[11] P. H. Quanjer, J. Stocks, G. Polgar, M. Wise, J. Karlberg, and G. Borsboom, "Compilation of reference values for lung function measurements in children," European Respiratory Journal, supplement, vol. 4, pp. 184S-261S, 1989.

[12] A. Morris, R. E. Kanner, R. Crapo, and R. Gardner, Clinical Pulmonary Function Testing. A Manual of Uniform Laboratory Procedures, Intermountain Thoracic Society, Salt Lake City, UT, USA, 1984.

[13] F. Messan, L. Lounana, and J. Medelli, "Exercise-induced bronchospasm in the warm humid climate of Benin," Medecine Tropicale, vol. 68, no. 5, article 550, 2008.

[14] B. G. Ferris, "Epidemiology standardization project (American Thoracic Society)," American Review of Respiratory Disease, vol. 118, no. 6, pp. 1-120, 1978.

[15] T. G. Lohman, A. F. Roche, and R. Martorell, Anthropometric Standardization Reference Manual, Human Kinetics Books, 1998.

[16] T. J. Cole, M. C. Bellizzi, K. M. Flegal, and W. H. Dietz, "Establishing a standard definition for child overweight and obesity worldwide: international survey," British Medical Journal, vol. 320, no. 7244, pp. 1240-1243, 2000.

[17] J. Wanger, J. L. Clausen, A. Coates et al., "Standardisation of the measurement of lung volumes," European Respiratory Journal, vol. 26, no. 3, pp. 511-522, 2005.

[18] P. H. Quanjer, A. Dalhuisen, and B. C. van Zomeren, "Summary equations of reference values," Bulletin Européen de Physiopathologie Respiratoire, vol. 19, pp. 45-51, 1983.

[19] J. L. Hankinson, J. R. Odencrantz, and K. B. Fedan, "Spirometric reference values from a sample of the general U.S. Population," American Journal of Respiratory and Critical Care Medicine, vol. 159, no. 1, pp. 179-187, 1999.

[20] J. H. Ware, D. W. Dockery, T. A. Louis, X. Xu, B. G. Ferris Jr., and F. E. Speizer, "Longitudinal and cross-sectional estimates of pulmonary function decline in never-smoking adults," American Journal of Epidemiology, vol. 132, no. 4, pp. 685-700, 1990.

[21] H. Guénard and S. Rouatbi, "Aspects physiologiques du vieillissement respiratoire," La Revue des Maladies Respiratoires, vol. 21, no. 5, part 3, pp. 13-24, 2004.

[22] R. L. Jensen, R. O. Crapo, A. K. Flint, and H. M. Howell, "Problems in selecting representative reference values for spirométrie," American Journal of Respiratory and Critical Care Medicine, vol. 165, article A200, 2002.

[23] M. Becklake, R. Crapo, S. Buist, B. Burrows, and J. Clausen, "Lung function testing: selection of reference values and interpretative strategies," American Thoracic Society. American Review of Respiratory Disease, vol. 144, pp. 1202-1218, 1991.

[24] B. Jordan, "DNA, genetic superiority and social, "race": the contribution of SNPs," Medicine and Science, vol. 26, no. 2, pp. 215-218, 2010.

[25] A. N. Aggarwal, D. Gupta, D. Behera, and S. K. Jindal, "Applicability of commonly used Caucasian prediction equations for spirometry interpretation in India,' Indian Journal of Medical Research, vol. 122, no. 2, pp. 153-164, 2005.

[26] R. O. Crapo, A. H. Morris, and R. M. Gardner, "Reference spirometric values using techniques and equipment that meet ATS recommendations," American Review of Respiratory Disease, vol. 123, no. 6, pp. 659-664, 1981.

[27] R. J. Knudson, M. D. Lebowitz, C. J. Holberg, and B. Burrows, "Changes in the normal maximal expiratory flow-volume curve with growth and aging," American Review of Respiratory Disease, vol. 127, no. 6, pp. 725-734, 1983.

[28] D. M. Olanrewaju, "Spirometric standards for healthy Nigerian children and adolescents," East African Medical Journal, vol. 68, no. 10, pp. 812-819, 1991.

[29] J. Kirkby, R. Bonner, S. Lum et al., "Interpretation of pediatric lung function: impact of ethnicity," Pediatric Pulmonology, vol. 48, no. 1, pp. 20-26, 2013.

[30] T. F. Leung, T. C. Liu, K. K. Mak et al., "Reference standards for forced expiratory indices in Chinese preschool children," Pediatric Pulmonology, 2013.

[31] P. Dufetel, K. Sambiani, K. Togbey, and M. Kolani, "Lung volume characteristics and expiratory flow seen in Black African adults," Revue des Maladies Respiratoires, vol. 7, no. 3, pp. 215222, 1990.

[32] C. A. de Castro Pereira, T. Sato, and S. C. Rodrigues, "New reference values for forced spirometry in white adults in Brazil," Jornal Brasileiro de Pneumologia, vol. 33, no. 4, pp. 397-406, 2007.

[33] S. Stanojevic, A. Wade, T. J. Cole, and J. Stocks, "Populationspecific reference equations?" European Respiratory Journal, vol. 29, no. 1, article 215, 2007.

[34] J. Paton, C. Beardsmore, A. Laverty et al., "Discrepancies between pediatric laboratories in pulmonary function results from healthy children," Pediatric Pulmonology, vol. 47, no. 6, pp. 588-596, 2012.

[35] G. B. Marks, "Are reference equations for spirometry an appropriate criterion for diagnosing disease and predicting prognosis?" Thorax, vol. 67, no. 1, pp. 85-87, 2012.

[36] P. H. Quanjer, S. Stanojevic, T. J. Cole et al., "ERS Global Lung Function Initiative. Multi-ethnic reference values for spirometry for the 3-95-yr age range: the global lung function 2012 equations," European Respiratory Journal, vol. 40, no. 6, pp. 1324-1343, 2012. 


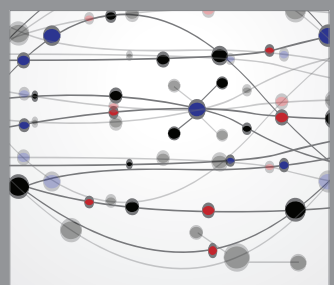

The Scientific World Journal
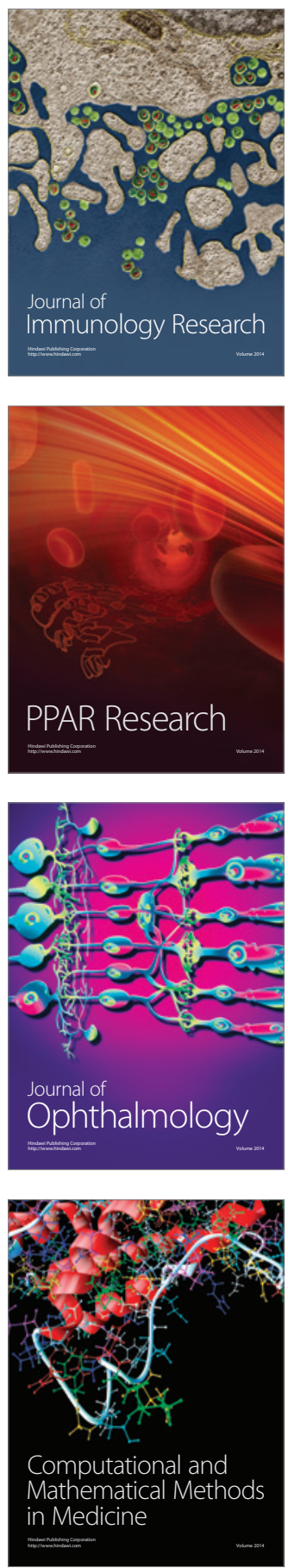

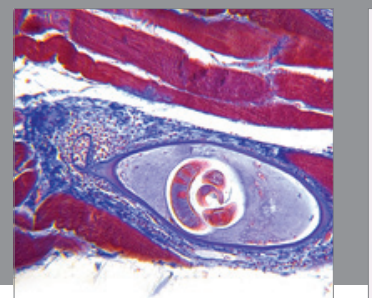

Gastroenterology

Research and Practice
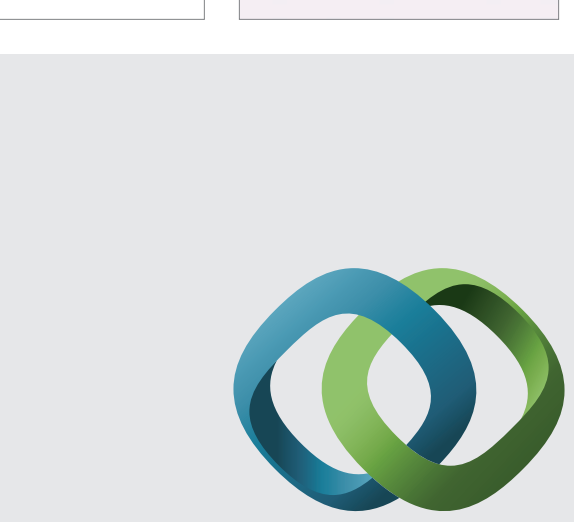

\section{Hindawi}

Submit your manuscripts at

http://www.hindawi.com
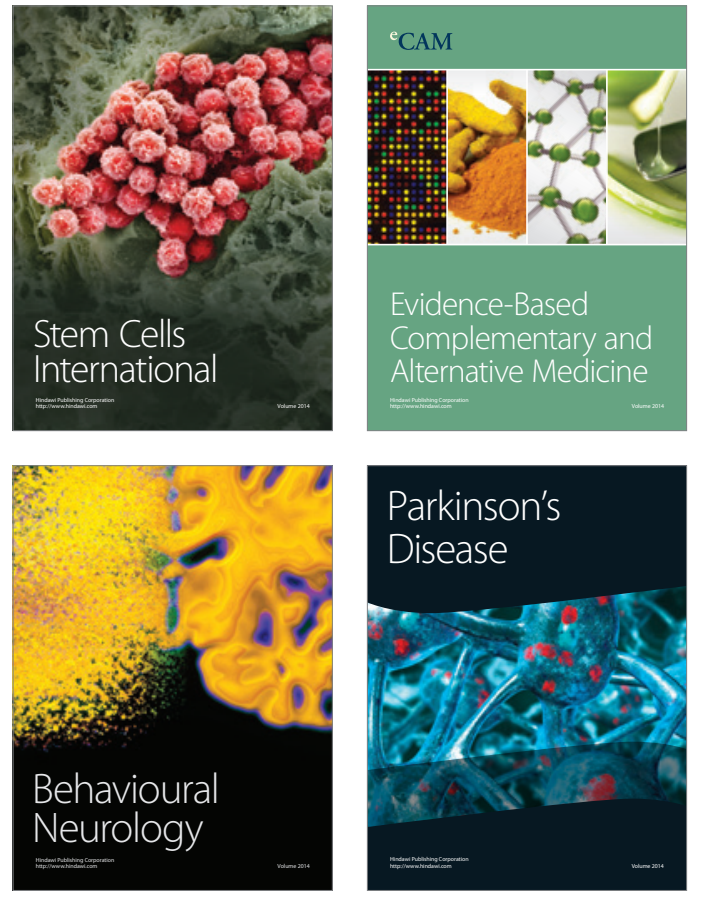
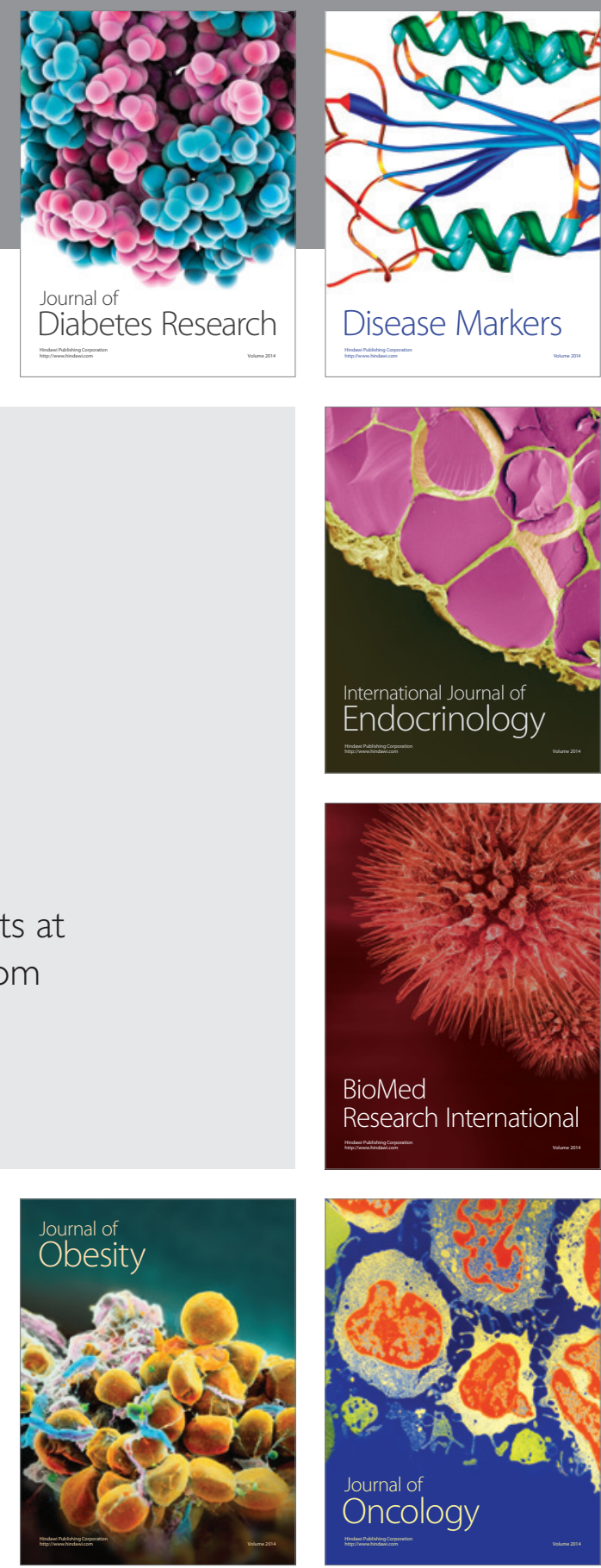

Disease Markers
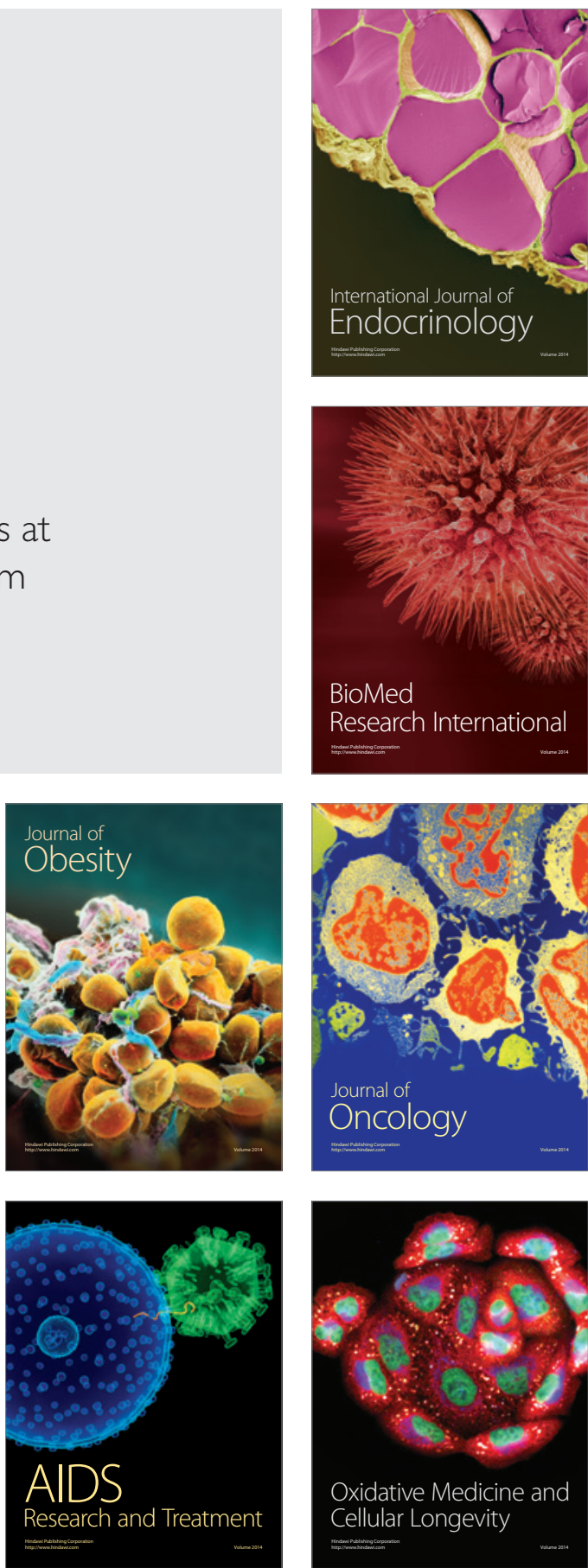